\title{
LINK BETWEEN TERRORISM AND SOCIAL, ECONOMIC AND SECURITY-POLITICAL FACTORS
}

\author{
JAN BŘEŇ ${ }^{1}$, TOMÁŠ ZEMAN ${ }^{1} \&$ RUDOLF URBAN ${ }^{2}$ \\ ${ }^{1}$ University of Defence, Czech Republic \\ ${ }^{2}$ The College of Regional Development and Banking Institute, Ambis, Czech Republic
}

\begin{abstract}
Terrorism is formulated as a planned use of violence targeting a wide range public. The aim of terrorism is to attract attention and cause fear through which specific political, religious or ideological intentions are achieved. An integral part of the issue of terrorism is not only the consequences of committed terrorist acts which lead to subsequent security measures but also the cause of terrorist activities which determine the reasons why people are motivated for these activities. The immediate causes of terrorist attacks vary on a case-by-case basis so their determination is not generally possible. However, it is possible to identify and analyze factors, which create preconditions for the emergence of terrorism. Some publications suggest that poor structural social conditions, economic deprivation and securitypolitical instability situations create frustration, which in turn makes terrorism more likely. The paper deals with the social factors (social inequality, standard of living, level of citizen's education), economic factors (GDP, unemployment, inflation) and security-political factors (corruption, criminality, political instability, government ineffectiveness, war and violent conflict) which potentially generate future terrorist activities. The main aim is to find out correlations between these factors and terrorism. In order to calculate results we gathered data (relevant indexes and indicators, which express individual social/economic/security-political factors) in 162 countries in the year 2017. Using Spearman's correlation coefficient as the statistical method, we made comprehensive statements about the link between individual social/economic/security-political factors and terrorism. Many previous analysis, studies and publications have focused on this issue but there are different statements about the causes of terrorism. This paper confirms some of these statements - that social inequality, GDP, current war conflict, corruption and political instability have increased the terrorist threat throughout the world. Keywords: factors, economic, factors, security-political, social, statistics.
\end{abstract}

\section{INTRODUCTION}

There are many factors in society, which motivate people to terrorist ideas and then to practical actions. Most of these factors come from social, economic and security-political area. It is possible to identify features or characteristics in these areas, which are common to a wide range of terrorist actors.

A publication by Ola [1] shows that citizen's social inequality leads to support and spread of terrorism in different countries in the world. High social inequalities produce isolation, poverty and aggression that may occur in frequent violent conflicts and terrorism. Government expenditures to social welfare of citizens are associated with reduction in terrorism. This is also confirmed by Lai's research [2]. Study by Azam and Thelen [3] shows there is positively link between level of citizen's education and terrorism. Considering the influence of education on terrorism, the findings of Drakos and Gofas [4] and KurrildKlitgaard et al. [5] do not indicate that education is significantly associated with terrorist attacks. Research by Krueger and Maleckova [6] points out that poor economic conditions of people do not affect the generation of terrorism to such extend. Piazza [7] in his research is convinced about very close link between citizens standard of living and the number of terrorist attacks despite of previous statement. Findings of Azam and Delacroix [8] also suggest that personal economic development significantly reduces the genesis of terrorism. 
Regarding to the link between economic performance and terrorism, the existing evidences are ambiguous. Publication by Blomberg and Hess [9] provides results that level of economic performance of state is associated with a higher number of terrorist attacks. Krueger and Laitin [10] note that there is no systematic link between economic performance of state and the evolution of terrorism. Their findings do not suggest that economic change translates into higher terrorist activity and further indicate that economic success exerts no independent effect of on terrorist attacks. Unemployment in general is a highly statistically significant predictor of terrorism. Goldstein study [11], which extensively analyses economic factors related to the risk of terrorism highlights unemployment, is an important aspect of terrorism causes. Piazza [12] focused on consumer prices fluctuations in relation to terrorist activities. The rise of prices is an indicator of positive correlation between inflation and terrorist activities. This was not confirmed by study of Campos and Gassebner [13]. Also study by Dural and Jahangir [14] does not confirm positive correlation. Even their conclusion is very different - increasing terrorism leads to decreasing inflation.

Corruption is other factor where is no consensus. A publication by Boussiga and Ghdamsi [15] reveals a long-term correlation relationship between corruption and terrorism. Simpson [16] found completely different results - there is no statistically significant relationship between those two variables. A publication by Odehnal and Sedlacik [17] points to dominant position of political instability as a determinant of terrorist activity. $\mathrm{Li}$ [18] in his publication that domestic political instability is actively entering and influencing terrorism. The findings also suggest several important policy implications. Democracy does not have a singularly positive effect on terrorism as is often claimed and found. By improving citizen satisfaction, electoral participation, and political efficacy, democratic governments can reduce the number of terrorist incidents within their border. Asongu et al. [19] confirms the fact government ineffectiveness has a major negative impact of the dynamics of terrorist activities. Freytag et al. [20] contests previous statement and their study shows that government ineffectiveness does not influence terrorism activities. There is no doubt about the strong link between factor of criminality and terrorism. The positively relationship is confirmed by Stanojoska's publication [21], which analyses the link between criminality, organized crime and terrorism. According to her statement, the connection between terrorisms and organized crime sometimes is very close and sometimes is even invisible. Some terrorist organizations started using organized crime acts; some organized crime networks started using terrorist acts. National and international violence conflicts (including wars) are one of the most important determinants, which generate terrorist activities according to Plamper and Neumayer [22].

Related to these analyses, studies and publications there are different statements about link between related factors from social/economic/security-political areas and terrorism. This paper finds out by using related statistical method relationship between terrorism threat and social inequality in society, level of citizen's education, standard of living, economic performance of state, unemployment, inflation, corruption, political instability, government ineffectiveness, criminality and war and violent conflict. According to results from this paper, it is possible to confirm conclusions of other authors described in this section.

\section{METHODS}

In the first stage, we established indicators and indexes, which expressed terrorism threat and individual social/economic/security-political factors (Table 1).

The dataset of these indexes and indicators comes from relevant sources and databases (Vision of Humanity, Social Progress Imperative, World Bank Open Data, Human Development Reports, The Global Economy and Transparency International). All these 
Table 1: Indexes and indicators for individual factors. (Source: Author's own construction.)

\begin{tabular}{|l|l|}
\hline FACTOR & INDEX INDICATOR \\
\hline Terrorism threat & Global Terrorism Index \\
\hline Social inequality in society & Social Progress Index \\
\hline Level of citizen's education & Education Index \\
\hline Standard of living & $\begin{array}{l}\text { Gross National Product per capita (purchasing parity } \\
\text { power) }\end{array}$ \\
\hline Economic performance of state & Gross Domestic Product per capita \\
\hline Unemployment & Unemployment rate \\
\hline Inflation & Consumer Price Index \\
\hline Corruption & Corruption Perceptions Index \\
\hline Political instability & Political Stability Index \\
\hline Government ineffectiveness & Government Effectiveness Index \\
\hline Criminality & Criminality Index \\
\hline War and violent conflict & Global Peace Index \\
\hline
\end{tabular}

indexes and indicators were considered in 162 countries from the year 2017 (more recent data is not available for all indexes and indicators). Based on these indexes and indicators we tested normality of the whole dataset for further statistical correlations. The normality of the dataset was not proved, so for the expression of correlations between related factors and terrorism threat the Spearman's correlation coefficient was selected. For the calculation of correlations and testing normality the IBM SPSS Statistics 25 [23] software was used. All correlations were determined using the 0.05 level of reliability ( $p$-value $\leq 0.05$ ) which means that the results were calculated with $95 \%$ probability of reliability.

\section{RESULTS AND DISCUSSION}

Statistical correlations in this section analyse link between related factors from social/economic/security-political areas and terrorism. Terrorist threat is expressed by Global Terrorism Index (GTI) [24], which provides a comprehensive summary of the key global trends and patterns in issue of terrorism. The overall score of GTI is quantified by a numeric value from 0 to 100 (the higher score, the higher terrorist threat is).

\subsection{Social factors}

Selected factors in this area: social inequality, citizen's standard of living and level of citizen's education.

\subsubsection{Social inequality}

Social inequality is expressed by Social Progress Index (SPI) [25], which measures the extent to which countries provide for the social and environmental needs of their citizens. Fifty-four indicators in the areas of basic human needs, foundations of well-being, and opportunity to progress show the relative performance of nations. The overall score of SPI is quantified by a numeric value from 0 to 100 (the higher score, the higher social inequality is). The result of correlation between terrorist threat and social inequality is described and explained in the following text, table and figures. 
Null hypothesis $\left(\mathrm{H}_{0}\right)$ : there is no correlation link between GTI and SPI. Alternative hypothesis $\left(\mathrm{H}_{1}\right)$ : there is correlation link between GTI and SPI.

According to the calculated correlation $\left(\mathrm{H}_{0}\right.$ is rejected, $\mathrm{H}_{1}$ is accepted, p-value $\left.\leq 0.05\right)$, there is a correlation link between GTI and SPI (Table 2) - the higher social inequality, the higher terrorist threat is (Fig. 1).

Table 2: Statistical correlation of GTI and SPI. (Source: Author's own construction.)

\begin{tabular}{|c|c|c|}
\hline LEVEL OF RELIABILITY & CORRELATION COEFFICIENT & P-VALUE \\
\hline 0.05 & 0.186 & 0.030 \\
\hline
\end{tabular}

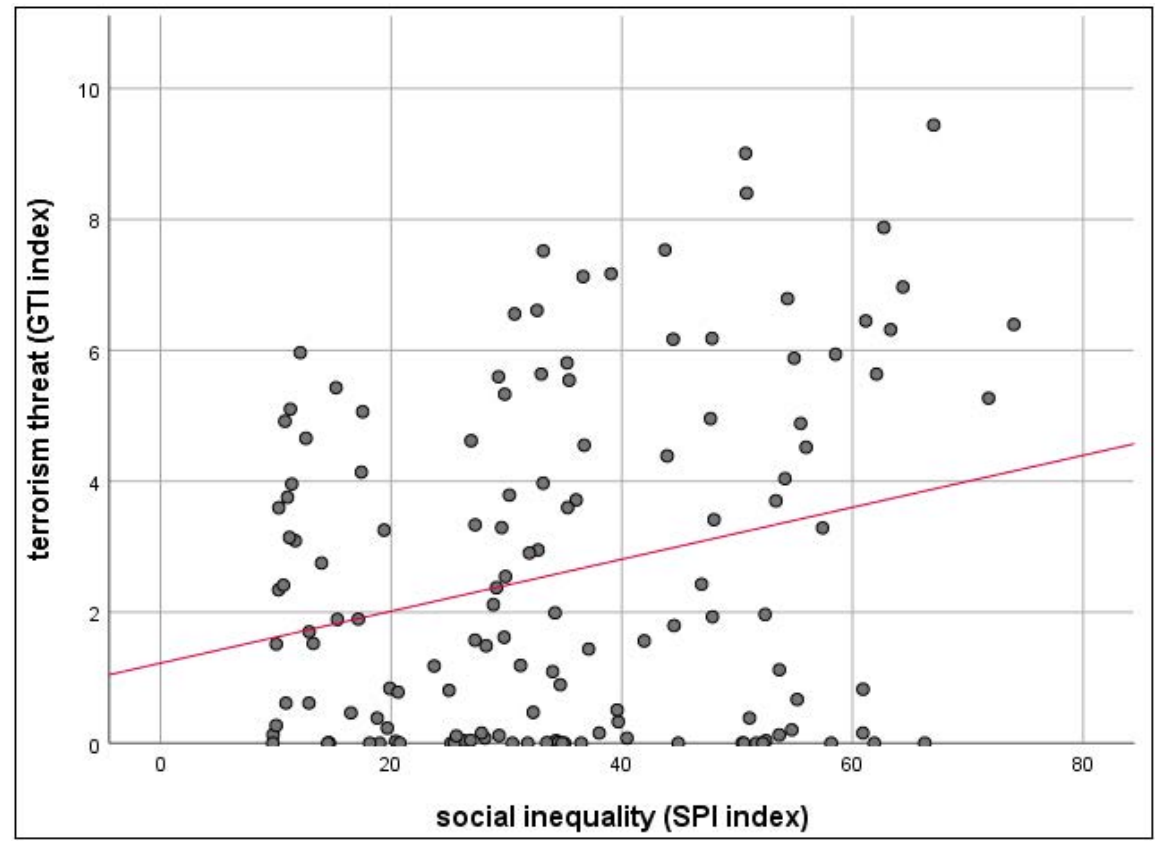

Figure 1: Statistical correlation of GTI and SPI. (Source: Author's own construction.)

\subsubsection{Standard of living}

Citizens standard of living is expressed by Gross National Income per capita at purchasing power parity (GNI per capita, PPP) [26]. GNI is the sum of value (in dollars) added by all resident producers plus any product taxes not included in the valuation of output plus net receipts of primary income from abroad. The result of correlation between terrorist threat and citizen's standard of living is described and explained in the following text and table.

$\mathrm{H}_{0}$ : there is no correlation link between GTI and GNI per capita, PPP.

$\mathrm{H}_{1}$ : there is correlation link between GTI and GNI per capita, PPP.

According to the calculated correlation $\left(\mathrm{H}_{0}\right.$ is accepted, $\mathrm{H}_{1}$ is rejected, $\mathrm{p}$-value $\geq 0.05$ ), there is no correlation link between GTI and GNI per capita, PPP (Table 3). 
Table 3: Statistical correlation of GTI and GNI per capita, PPP. (Source: Author's own construction.)

\begin{tabular}{|c|c|c|}
\hline LEVEL OF RELIABILITY & CORRELATION COEFFICIENT & P-VALUE \\
\hline 0.05 & -0.107 & 0.190 \\
\hline
\end{tabular}

3.1.3 Level of citizen's education

Level of citizen's education is expressed by Education Index (EI) [27], which calculated years of schooling and expected years of schooling. The overall score of EI is quantified by a numeric value from 0 to 1 (the higher score, the higher level of citizen's education is). The result of correlation between terrorist threat and citizen's level of education is described and explained in the following text and table.

$\mathrm{H}_{0}$ : there is no correlation link between GTI and EI.

$\mathrm{H}_{1}$ : there is correlation link between GTI and EI.

According to the calculated correlation $\left(\mathrm{H}_{0}\right.$ is accepted, $\mathrm{H}_{1}$ is rejected, $\mathrm{p}$-value $\left.\geq 0.05\right)$, there is no correlation link between GTI and EI (Table 4).

Table 4: Statistical correlation of GTI and EI. (Source: Author's own construction.)

\begin{tabular}{|c|c|c|}
\hline LEVEL OF RELIABILITY & CORRELATION COEFFICIENT & P-VALUE \\
\hline 0.05 & -0.130 & 0.105 \\
\hline
\end{tabular}

\subsection{Economic factors}

Economic factors in this area: unemployment, economic performance of state and inflation.

\subsubsection{Unemployment}

Percentage of unemployed citizens in the country expresses factor of unemployment. Data about this percentage number comes from database The World Bank [28]. The result of correlation between terrorist threat and unemployment is described and explained in the following text and table.

$\mathrm{H}_{0}$ : there is no correlation link between GTI and unemployment.

$\mathrm{H}_{1}$ : there is correlation link between GTI and unemployment.

According to the calculated correlation $\left(\mathrm{H}_{0}\right.$ is accepted, $\mathrm{H}_{1}$ is rejected, $\mathrm{p}$-value $\left.\geq 0.05\right)$, there is no correlation link between GTI and unemployment (Table 5).

Table 5: Statistical correlation of GTI and unemployment. (Source: Author's own construction.)

\begin{tabular}{|c|c|c|}
\hline LEVEL OF RELIABILITY & CORRELATION COEFFICIENT & P-VALUE \\
\hline 0.05 & 0.067 & 0.403 \\
\hline
\end{tabular}




\subsubsection{Economic performance of state}

Gross Domestic Product per capita (GDP per capita) [29] expresses economic performance of state. GDP per capita is a measure of a country's economic output that accounts for its number of people. The result of correlation between terrorist threat and economic performance of state is described and explained in the following text, table and figure.

$\mathrm{H}_{0}$ : there is no correlation link between GTI and economic performance of state.

$\mathrm{H}_{1}$ : there is correlation link between GTI and economic performance of state.

According to the calculated correlation $\left(\mathrm{H}_{0}\right.$ is rejected, $\mathrm{H}_{1}$ is accepted, $\mathrm{p}$-value $\left.\leq 0.05\right)$, there is a correlation link between GTI and GDP per capita (Table 6) - the higher economic performance of state in the country, the lower terrorist threat is (Fig. 2).

Table 6: Statistical correlation of GTI and economic performance of state. (Source: Author's own construction.)

\begin{tabular}{|c|c|c|}
\hline LEVEL OF RELIABILITY & CORRELATION COEFFICIENT & P-VALUE \\
\hline 0.05 & -0.178 & 0.041 \\
\hline
\end{tabular}

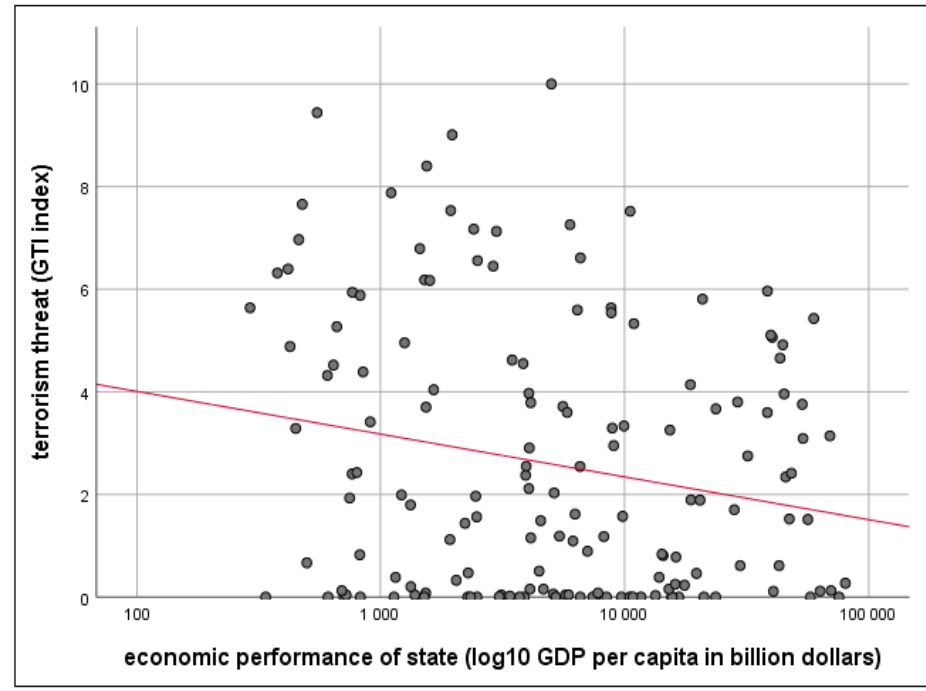

Figure 2: Statistical correlation of GTI and economic performance of state. (Source: Author's own construction.)

\subsubsection{Inflation}

Inflation rate is expressed by Customer Price Index (CPI) [30], which measures average change in prices over time that consumers pay for a basket of goods and services. The result of correlation between terrorist threat and inflation is described and explained in the following text and table.

$\mathrm{H}_{0}$ : there is no correlation link between GTI and CPI.

$\mathrm{H}_{1}$ : there is correlation link between GTI and CPI. 
According to the calculated correlation $\left(\mathrm{H}_{0}\right.$ is accepted, $\mathrm{H}_{1}$ is rejected, $\mathrm{p}$-value $\left.\geq 0.05\right)$, there is no correlation link between GTI and CPI (Table 7).

Table 7: Statistical correlation of GTI and CPI. (Source: Author's own construction.)

\begin{tabular}{|c|c|c|}
\hline LEVEL OF RELIABILITY & CORRELATION COEFFICIENT & P-VALUE \\
\hline 0.05 & 0.145 & 0.084 \\
\hline
\end{tabular}

\subsection{Security: Political factors}

Security: political factors in this area: war and violent conflict, criminality, political instability, government ineffectiveness and corruption.

\subsubsection{War and violent conflict}

Global Peace Index (GPI) [31] expresses factor of war and violent conflict. GPI measures the relative position of nations' and regions' peacefulness. The overall score of GPI is quantified by a numeric value from 0 to 5 (the higher score, the higher intensity of war and violent conflict is). The result of correlation between terrorist threat and war conflict is described and explained in the following text, table and figure.

$\mathrm{H}_{0}$ : there is no correlation link between GTI and GPI.

$\mathrm{H}_{1}$ : there is correlation link between GTI and GPI.

According to the calculated correlation $\left(\mathrm{H}_{0}\right.$ is rejected, $\mathrm{H}_{1}$ is accepted, $\mathrm{p}$-value $\left.\leq 0.05\right)$, there is a correlation link between GTI and GPI (Table 8) - the higher intensity of war and violent conflict in the country, the higher terrorist threat is (Fig. 3).

Table 8: Statistical correlation of GTI and GPI. (Source: Author's own construction.)

\begin{tabular}{|c|c|c|}
\hline LEVEL OF RELIABILITY & CORRELATION COEFFICIENT & P-VALUE \\
\hline 0.05 & 0.491 & 0.000 \\
\hline
\end{tabular}

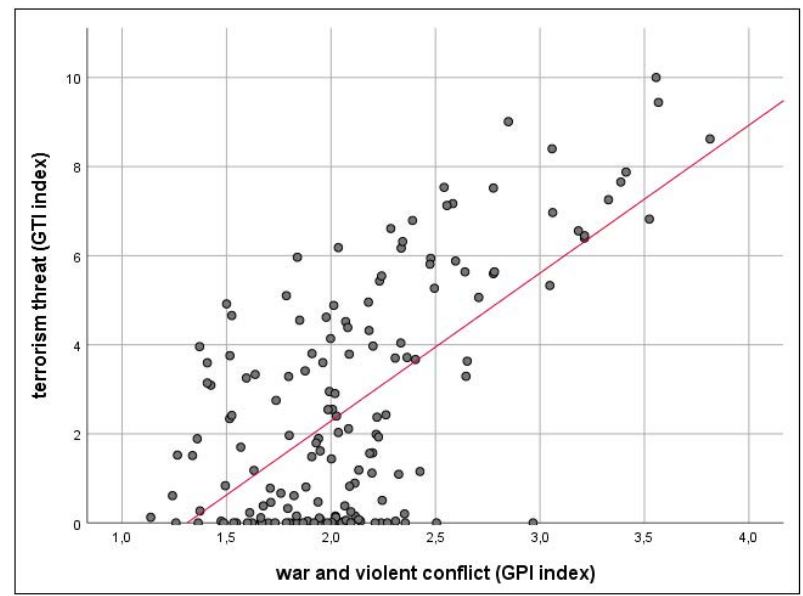

Figure 3: Statistical correlation of GTI and GPI. (Source: Author's own construction.) 


\subsubsection{Criminality}

Crime index (CI) [32] expresses factor of national criminality. The overall score of GPI is quantified by a numeric value from 0 to 100 (the higher the score, the higher intensity criminality is). The result of correlation between terrorist threat and criminality is described and explained in the following text and table.

$\mathrm{H}_{0}$ : there is no correlation link between GTI and CI.

$\mathrm{H}_{1}$ : there is correlation link between GTI and CI.

According to the calculated correlation $\left(\mathrm{H}_{0}\right.$ is accepted, $\mathrm{H}_{1}$ is rejected, p-value $\left.\geq 0.05\right)$, there is no correlation link between GTI and CI (Table 9).

Table 9: Statistical correlation of GTI and CI. (Source: Author's own construction.)

\begin{tabular}{|c|c|c|}
\hline LEVEL OF RELIABILITY & CORRELATION COEFFICIENT & P-VALUE \\
\hline 0.05 & 0.154 & 0.100 \\
\hline
\end{tabular}

\subsubsection{Political instability}

Political Instability is expressed by Political Stability Index (PSI) [33]. The overall score of PSI is quantified by a numeric value from -3 to 3 (the higher score, the higher political stability is). The result of correlation between terrorist threat and political instability is described and explained in the following text, table and figure.

$\mathrm{H}_{0}$ : there is no correlation link between GTI and PSI.

$\mathrm{H}_{1}$ : there is correlation link between GTI and PSI.

According to the calculated correlation $\left(\mathrm{H}_{0}\right.$ is rejected, $\mathrm{H}_{1}$ is accepted, p-value $\left.\leq 0.05\right)$, there is a correlation link between GTI and PSI (Table 10) - the higher political instability in the country, the higher terrorist threat is (Fig. 4).

Table 10: Statistical correlation of GTI and PSI. (Source: Author's own construction.)

\begin{tabular}{|c|c|c|}
\hline LEVEL OF RELIABILITY & CORRELATION COEFFICIENT & P-VALUE \\
\hline 0.05 & -0.590 & 0.000 \\
\hline
\end{tabular}

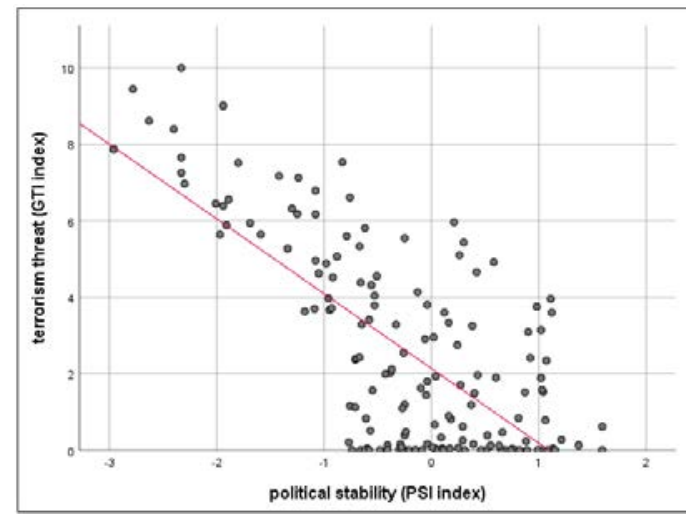

Figure 4: Statistical correlation of GTI and GPI. (Source: Author's own construction.) 


\subsubsection{Government ineffectiveness}

Government Effectiveness Index (GEI) [34] expresses factor of government ineffectiveness. GEI captures perceptions of the quality of public services, the quality of the civil service and the degree of its independence from political pressure, the quality of policy formulation and implementation, and the credibility of the government's commitment to such policies. The overall score of GEI is quantified by a numeric value from -2.5 to 2.5 (the higher score, the higher government effectiveness is). The result of correlation between terrorist threat and government effectiveness is described and explained in the following text and table.

$\mathrm{H}_{0}$ : there is no correlation link between GTI and GEI.

$\mathrm{H}_{1}$ : there is correlation link between GTI and GEI.

According to the calculated correlation $\left(\mathrm{H}_{0}\right.$ is accepted, $\mathrm{H}_{1}$ is rejected, $\mathrm{p}$-value $\geq 0.05$ ), there is no correlation link between GTI and GEI (Table 11).

Table 11: Statistical correlation of GTI and GEI. (Source: Author's own construction.)

\begin{tabular}{|c|c|c|}
\hline LEVEL OF RELIABILITY & CORRELATION COEFFICIENT & P-VALUE \\
\hline 0.05 & -0.066 & 0.410 \\
\hline
\end{tabular}

\subsubsection{Corruption}

Factor of corruption is expressed by Corruption Perception Index (CPI) [35]. CPI ranks countries by their perceived levels of public sector corruption, as determined by expert assessments and opinion surveys. The overall score of CPI is quantified by a numeric value from 0 to 100 (the higher score, the higher corruption is). The result of correlation between terrorist threat and corruption is described and explained in the following text, table and figure.

$\mathrm{H}_{0}$ : there is no correlation link between GTI and CPI.

$\mathrm{H}_{1}$ : there is correlation link between GTI and CPI.

According to the calculated correlation $\left(\mathrm{H}_{0}\right.$ is rejected, $\mathrm{H}_{1}$ is accepted, $\mathrm{p}$-value $\left.\leq 0.05\right)$, there is a correlation link between GTI and PSI (Table 12) - the higher corruption in the country, the higher terrorist threat is (Fig. 5).

Table 12: Statistical correlation of GTI and CPI. (Source: Author's own construction.)

\begin{tabular}{|c|c|c|}
\hline LEVEL OF RELIABILITY & CORRELATION COEFFICIENT & P-VALUE \\
\hline 0.05 & 0.165 & 0.041 \\
\hline
\end{tabular}

\section{CONCLUSION}

Based on our results, there are correlations link between terrorism and some factors from social/economical/security-political areas in 162 countries in the year 2017. Social inequality in society, economic performance of state, war and violent conflict, corruption in state and state's political instability have influenced terrorism. The results have been confirmed with $95 \%$ probability of reliability. 


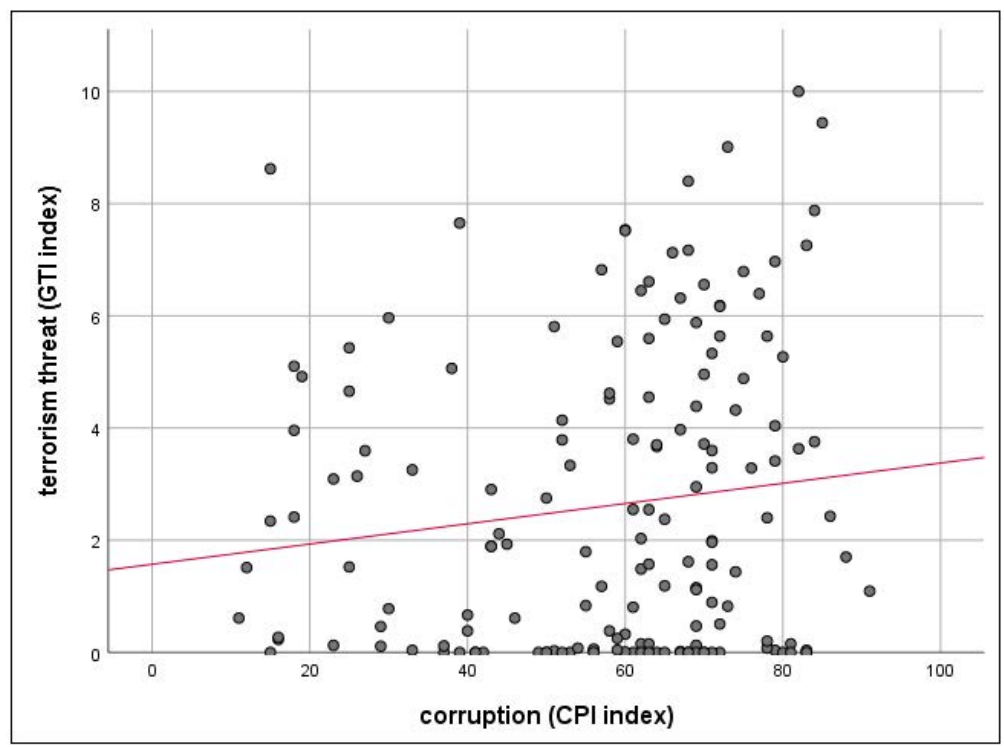

Figure 5: Statistical correlation of GTI and CPI. (Source: Author's own construction.)

Terrorist attacks are different and each of them is characterized by individual and specific form, type and motivational character of the realization. These aspects of terrorism are extensive and complex issue of modern society.

\section{ACKNOWLEDGEMENT}

This paper was supported by the Ministry of Education, Youth and Sports of the Czech Republic (SV18-FVL-K106-BŘE).

\section{REFERENCES}

[1] Ola, T., Re-thinking poverty, inequality and their relationship to terrorism. Journal of Sciences: Basic and Applied Research, 21(2), pp. 264-292, 2018.

[2] Lai, B., Draining the swamp: An empirical examination of the production of international terrorism. Conflict Management and Peace Science, 24(4), pp. 297-310, 2016.

[3] Azam, J.P. \& Thelen, V., The roles of foreign aid and education in the war on terror. Public Choice, 135(3-4), pp. 375-397, 2008.

[4] Drakos, K. \& Gofas, A., In search of the average transtational terrorist attack venue. Defence and Peace Economics, 17(2), pp. 73-93, 2006.

[5] Kurrild-Klitgaard, P., Justesen, M.K. \& Klemmensen, R., The political economy of freedom, democracy and transnational terrorism. Public Choice, 128(1/2), pp. 289315, 2006.

[6] Krueger, A.B. \& Maleckova, J., Education, poverty and terrorism: Is there a causal connection? Journal of Economic Perspectives, 17(4), pp. 119-144, 2003.

[7] Piazza, J.A., Poverty, minority economic discrimination, and domestic terrorism. Journal of Peace Research, 48(3), pp. 339-353, 2011.

[8] Azam, J.-P. \& Delacroix, A., Aid and the delegated fight against terrorism. Review of Development Economic, 10(2), pp. 330-344, 2006. 
[9] Blomberg, S.B. \& Hess, G.D., From (no) butter to guns? Understanding the economic role in transnational terrorism. SSRN Electronic Journal, 2006.

[10] Krueger, A.B. \& Laitin, D., Kto Kogo? A cross-country study of the origins and targets of terrorism. Terrorism, Economic Development, and Political Openness, pp. 148$173,2008$.

[11] Goldstein, K., Unemployment, inequality and terrorism: another look at the relationship between economics and terrorism. Undergraduate Economic Review, 1(1), 2003.

[12] Piazza, J., The cost of living and terror: Does consumer price volatility fuel terrorism? Southern Economic Journal, 79(4), pp. 812-231, 2013.

[13] Campos, N. \& Gassebner, M., International terrorism, domestic political instability, and the escalation effect. Economics \& Politics, 25(1), pp. 27-47, 2013.

[14] Dural, B.Y. \& Jahangir, S.M.R., Relationship between terrorism and macroeconomic variables: Especially import of crude oil and natural gas in Turkey. Ulakbilge, 5(14), pp. 1373-1394, 2009.

[15] Boussiga, N. \& Ghdamsi, M., The corruption-terrorism nexus: A panel data approach. International Journal of Economics and Finance, 8(11), pp. 111-117, 2016.

[16] Simpson, M., Terrorism and corruption. International Journal of Sociology, 44(2), pp. 87-104, 2014.

[17] Odehnal, J. \& Sedlacik, M., Political stability as determinant of terrorist attacks in developed and developing countries: An empirical multivariate classification analysis. AIP Conference Proceedings, 2018.

[18] Li, Q., Does democracy promote or reduce transnational terrorist incidents? Journal of Conflict Resolution, 49(2), pp. 278-297, 2016.

[19] Asongu, S., Tchamyou, V., Asongu, N. \& Tchamynou, N., Fighting terrorism in Africa: Evidence from bundling and unbundling institutions. Empirical Economics, 56(3), pp. 883-933, 2019.

[20] Freytag, A., Krueger, J.J. \& Meierreieks, D., The origins of terrorism: cross-country estimates on socio-economic determinants of terrorism. Economics of Security Working Paper 27, 2010.

[21] Stanojoska, A., The connection between terrorism and organized crime: Narcoterrosism and the other hybrids. Combating Terrorism: International Standards and Legislation Conference Proceedings, 2011.

[22] Plamper, T. \& Neumayer, T., The friend of my enemy is my enemy: International alliances and international terrorism. European Journal of Political Research, 49(1), pp. 75-96, 2010.

[23] IBM Corp., IBM SPSS Statistics for Windows, Version 25.0, Released 2017. Armonk, NY: IBM Corp.

[24] Vision of Humanity, Global Terrorism Index 2017. http://visionofhumanity.org/app/ uploads/2017/11/Global-Terrorism-Index-2017.pdf. Accessed on: 7 Aug. 2019.

[25] Social Progress Imperative, 2017 Social Progress Index. www.socialprogress.org/. Accessed on: 7 Aug. 2019.

[26] The World Bank, GNI per capita, PPP (current international dollars). https://data.worldbank.org/indicator/ny.gnp.pcap.pp.cd. Accessed on: 7 Aug. 2019.

[27] Human Development Report, Education Index. http://hdr.undp.org/en/content/ education-index. Accessed on: 7 Aug. 2019.

[28] The World Bank, Unemployment, total (\% of total labour force). https://data.worldbank.org/indicator/SL.UEM.TOTL.ZS. Accessed on: 8 Aug. 2019.

[29] The World Bank, GDP per capita (current US dollars). 
https://data.worldbank.org/indicator/ny.gdp.pcap.cd. Accessed on: 8 Aug. 2019.

[30] The World Bank, Inflation, consumer prices (annual \%). https://data.worldbank.org/indicator/FP.CPI.TOTL.ZG. Accessed on: 8 Aug. 2019.

[31] Vision of Humanity, Global Peace Index 2017. https://reliefweb.int/sites/reliefweb.int/ files/resources/GPI-2017-Report-1.pdf. Accessed on: 8 Aug. 2019.

[32] Numbeo Database, Crime Index for Country 2017. www.numbeo.com/crime/rankings_by_country.jsp?title=2017. Accessed on: 8 Aug. 2019.

[33] The Global Economy, Political stability - Country rankings. www.theglobaleconomy.com/rankings/wb_political_stability/. Accessed on: 8 Aug. 2019.

[34] The World Bank, Government Effectiveness. https://tcdata360.worldbank.org/ indicators $/ \mathrm{h} 1 \mathrm{c} 9 \mathrm{~d} 2797$ ? country $=$ BRA\&indicator $=388 \& \mathrm{viz}=$ line_chart\&years $=$ 1996,2017. Accessed on: 8 Aug. 2019.

[35] Transparency International, Index 2017. www.transparency.org/news/feature/ corruption_perceptions_index_2017. Accessed on: 8 Aug. 2019. 